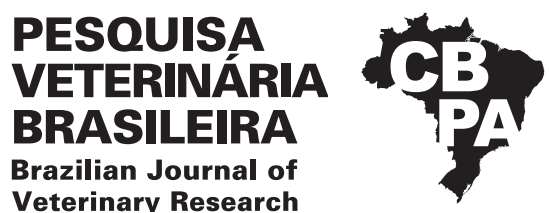

\title{
Horses fed meal contaminated with mycotoxins performing short-term exercises ${ }^{1}$
}

\author{
Auro César Braga ${ }^{2 *}$ (D), Fernando Q. Almeida ${ }^{3}$, Vinicius P. Silva ${ }^{4}$, Maria I.V. Almeida ${ }^{5}$, \\ Kelly M. Keller ${ }^{6}$, Vinícius A. Diegues ${ }^{7}$, Freddy R. Thomes ${ }^{8}$ and Carlos A.R. Rosa ${ }^{9}$
}

\begin{abstract}
Braga A.C., Almeida F.Q., Silva V.P., Almeida M.I.V., Keller K.M., Diegues V.A., Thomes F.R. \& Rosa C.A.R. 2020. Horses fed meal contaminated with mycotoxins performing short-term exercises. Pesquisa Veterinária Brasileira 40(9):717-725. Programa de Pós-Graduação em Ciência, Tecnologia e Inovação em Agropecuária, Universidade Federal Rural do Rio de Janeiro, Rodovia BR-465 Km 7, Seropédica, RJ 23890-000, Brazil. E-mail: auro_vet@hotmail.com

This research was carried out to evaluate the effect of mycotoxins on the performance of horses through physiological parameters, and hematology and serum biochemistry analyses. The essay lasted 40 days, with 12 days for adaptation and 28 days of experimentation. In the experimental stage, the horses were distributed in a completely randomized design, with three treatments with four animals each. The treatments used were 0 (control), $50 \mathrm{ppb}$ and $100 \mathrm{ppb}$ of Aflatoxin $\mathrm{B}_{1}\left(\mathrm{AFB}_{1}\right)$ added to a concentrate in a basal diet. The basal diet contained mycotoxins from feedstuffs naturally contaminated. The exercise test was performed over the 21th day of the experimental stage. The exercise consisted in an interval training test with a warm-up of 17 mins at a trot followed by three gallops of $450 \mathrm{~m} / \mathrm{min}$. The heart rate was monitored between the gallops. Before the exercise test and immediately after the third gallop, the physiological and blood parameters were evaluated, and continued up to 48 hours after the exercise. The results of the physiological, hematological and biochemical parameters were submitted to analysis of variance (ANOVA) and compared by the Tukey test at $5 \%$ of significance. The presence of $\mathrm{AFB}_{1}$ in the diet influenced the alkaline phosphatase activity, which presented higher values in horses fed diet with inclusion of $100 \mathrm{ppb} \mathrm{AFB}_{1}$, suggesting a hepatotoxic activity associated with the others mycotoxins naturally present in the feedstuffs.
\end{abstract}

INDEX TERMS: Horses, contaminated meal, short-term exercises, alkaline phosphatase, exercise, mycotoxins, morphology.

RESUMO.- [Efeitos das micotoxinas na performance de equinos submetidos a exercícios de curta duração.] Esta pesquisa foi conduzida para avaliar o efeito de micotoxinas no desempenho de equinos com avaliações fisiológicas e análises

\footnotetext{
${ }^{1}$ Received on May 25, 2020.

Accepted for publication on July 2, 2020

${ }^{2}$ Graduate Program in Science, Technology and Innovation in Agriculture, Universidade Federal Rural do Rio de Janeiro (UFRRJ), Rodovia BR-465 Km 7 , Seropédica, RJ 23890-000, Brazil. *Corresponding author: auro_vet@hotmail.com

${ }^{3}$ Instituto de Veterinária, Universidade Federal Rural do Rio de Janeiro (UFRRJ), Rodovia BR-465 Km 7, Seropédica, RJ 23890-000, Brazil. E-mail: almeidafq@yahoo.com.br

${ }^{4}$ Instituto de Zootecnia, Universidade Federal Rural do Rio de Janeiro (UFRRJ), Rodovia BR-465, Km 7, Seropédica, RJ 23890-000, Brazil. E-mail: pimentelzootec@gmail.com

${ }^{5}$ Departamento de Zootecnia, Universidade Federal do Espirito Santo (UFES), Alto Universitário s/n, Guararema, Alegre, ES 29500-000, Brazil. E-mail: almeidamiv@hotmail.com
}

hematológicas e da bioquímica sérica. 0 ensaio durou 40 dias, com 12 dias de adaptação e 28 dias de experimentação. $\mathrm{Na}$ fase experimental, os equinos foram distribuídos em delineamento inteiramente casualizado em três tratamentos,

\footnotetext{
${ }^{6}$ Escola de Veterinária, Universidade Federal de Minas Gerais (UFMG), Campus Pampulha, Av. Antônio Carlos 6627, São Luiz, Belo Horizonte, MG 31270-901, Brazil. E-mail: kelly.medvet@gmail.com

${ }^{7}$ Seção de Veterinária, Escola de Sargentos das Armas (ESA), Av. Sete de Setembro 628, Três Corações, MG 37410-000, Brazil. E-mail: viniciusdieguesvet@hotmail.com

${ }^{8}$ Seção de Veterinária, Escola de Sargentos das Armas (ESA), Av. Sete de Setembro 628, Três Corações, MG 37410000, Brazil. E-mail: freddythomes@yahoo.com.br

${ }^{9}$ Instituto de Veterinária, Universidade Federal Rural do Rio de Janeiro (UFRRJ), Rodovia BR-465 Km 7, Seropédica, RJ 23890-000, Brazil. E-mail: shalako1953@gmail.com
} 
com quatro animais cada. Os tratamentos utilizados foram 0 (controle), 50 ppb e 100 ppb de Aflatoxina $B_{1}\left(A_{1} B_{1}\right.$ ) adicionada ao concentrado de uma dieta basal. A dieta basal continha alimentos naturalmente contaminados por micotoxinas. 0 teste de desempenho foi executado no $21^{\circ}$ dia da fase experimental por meio de teste intervalado consistindo em aquecimento ao trote por 17 minutos, seguido de três galopes de $450 \mathrm{~m} / \mathrm{min}$. A frequência cardíaca (FC) foi monitorada entre os galopes. Antes do exercício e imediatamente após o terceiro galope, os parâmetros fisiológicos e sanguíneos foram avaliados e continuaram sendo monitorados até 48 horas após o exercício. Os resultados dos parâmetros fisiológicos, hematológicos e bioquímicos foram submetidos à análise de variância (ANOVA) e comparados pelo teste de Tukey a $5 \%$ de significância. A presença de $\mathrm{AFB}_{1}$ na dieta influenciou a atividade da fosfatase alcalina, que apresentou valores mais elevadas na dieta com inclusão de 100 ppb de $\mathrm{AFB}_{1}$, sugerindo uma atividade hepatotóxica associada às outras micotoxinas naturalmente presentes nos alimentos.

TERMOS DE INDEXAÇÃO: Micotoxinas, equinos, exercícios de curta duração, fosfatase alcalina, micotoxinas, morfologia.

\section{INTRODUCTION}

Several mycotoxins have been identified in foods and diets for humans and animals in Brazil. The importance of aflatoxins (AF), fumonisins (FB), ochratoxins (OTA), zearalenone (ZEA) and trichothecenes should be emphasized due to their occurrence and also their high toxigenic potential for farm animals (Baldissera et al. 1993, Franco et al. 2019). In addition, the additive or synergistic effect between different toxins, which increase or alter their effects on animals, should be considered. Although mycotoxins have several adverse effects on animal health, little is known about their impacts in the horse nutrition (Liesener et al. 2010, Schumann et al. 2016). Raymond et al. (2005) pointed out that, especially for sport horses, chronic intake of low mycotoxin levels in diets can affect performance without animals showing typical clinical signs of mycotoxicosis.

Aflatoxins are a class of carcinogenic mycotoxins produced by Aspergillus fungi and are widely distributed in nature, especially in a variety of food commodities. Aflatoxin $\mathrm{B}_{1}$ $\left(A F B_{1}\right)$ is confirmed to be the most toxic of all the aflatoxins and has been well-characterized to lead to the development of hepatic cellular carcinoma (HCC) in humans and animals. The occurrence of these mycotoxins, alone and in combination, representes a real risk for human and animal health (Bertero et al. 2018, Rushing \& Selim 2019).

Although the importance of mycotoxins in public and animal health is recognized, there is no uniform regulation of mycotoxin limits in foods in the different countries, particularly in Mercosur countries (Brazil/Argentina), (Mercosul/GMC 2002). The Brazilian legislation (Brasil 1988) establishes the maximum limit of $50 \mu \mathrm{g} / \mathrm{kg}$ for aflatoxins in any feedstuffs used directly or as an ingredient in diets for animals but does not specify limits for other mycotoxins. This research was carried out to evaluate the inclusion of aflatoxin B1 $\left(\mathrm{AFB}_{1}\right)$ in the diet and to verify the effects on metabolism and performance of horses.

\section{MATERIALS AND METHODS}

The experiment was conducted at the Army Sergeant School (ESA), latitude $21^{\circ} 42^{\prime} 15.6^{\prime \prime}$ South and longitude 4515'18.9" West, of the Brazilian Army, in Três Corações, Minas Gerais State. The assay was performed in accordance with the principles of ethics in experimentation approved by the committee on ethics in animal experimentation from the University: CEUA-UFRRJ Number 1212031017.

Experimental period. The total experimental period was 40 days, divided into two stages: one was the pre-experimental or adaption stage of 12 days and the other was the experimental stage of 28 days. A total of 12 adult Brazilian Sport Horses $(9$ females and 3 males), aged between 5 and 8 years old with an average body weight of $458.02 \pm 22.09 \mathrm{~kg}$ were used. The research was conducted in a completely randomized design, with three treatments with four animals each, and the animal was the experimental unit. The experimental treatments used were: Treatment $\mathrm{I}=$ control diet $\left(0 \mu \mathrm{g} / \mathrm{kg}\right.$ of $\left.\mathrm{AFB}_{1}\right)$; Treatment II = diet with $50 \mu \mathrm{g} / \mathrm{kg}$ of $\mathrm{AFB}_{1}$; and

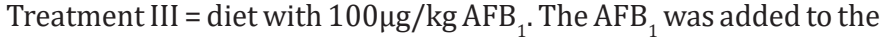
basal diet (Table 1). The experimental basal diet was composed by Tifton hay (Cynodon spp.) and alfafa (Medicago sativa), commercial concentrate (S Line -280, Royal Horse ${ }^{\circledR}$ ), mineral salt and water ad libitum, elaborated according to the NRC (2007) for mature horses. The horses remained free in their paddocks during the day and were housed in individual stalls at night. The animals were fed according to the schedule of the Military Unit, which is $2 \mathrm{~kg}$ of concentrate meal at 05:00 a.m. and $2 \mathrm{~kg}$ at 17:00 p.m., alfafa hay at 10:00 a.m., and tifton hay at 13:00 p.m. and 20:00 p.m. Every day during the experimental period at the 17:00 p.m. feeding time, $1 \mathrm{~kg}$ of concentrate feed with $\mathrm{AFB}_{1}$ was prepared and given to the animals, according to the treatment. Before the adaptation period, all feedstuffs were analyzed, and the concentrations of mycotoxins in the basal diet were: $5.620 \mu \mathrm{g} / \mathrm{kg}$ of DON, $708 \mu \mathrm{g} / \mathrm{kg}$ of ZEA and $560 \mu \mathrm{g} / \mathrm{kg}$ of $\mathrm{FB}_{1}$

Clinical conditions. Before, during and after the experimental period, clinical, hematological and biochemical analyzes of the horses were carried out to check the health conditions, especially regarding the presence of liver damage. Throughout the experimental period, the clinical conditions of the animals were monitored, daily, by a veterinarian.

Aflatoxin production and estimation. The aflatoxin $B_{1}$ was produced by the Mycology Laboratory of Federal University Rural of Rio de Janeiro from fermenting rice with a spore suspension of Aspergillus parasiticus (NRRL 2999), according to Shotwell et al. (1966). The $\mathrm{AFB}_{1}$ content was extracted and purified through a Mycosep ${ }^{\circledR}$ Aflazon column (Romer Labs Diagnostic GmbH., Tulln,

Table 1. The average composition ( $\mathrm{g}$ or $\mu \mathrm{g} / \mathrm{kg}$ on dry matter basis) of the experimental diets with different inclusions of $\mathrm{AFB}_{1}$

\begin{tabular}{lccc}
\hline \multirow{2}{*}{ Diet Components } & \multicolumn{3}{c}{ Treatments } \\
\cline { 2 - 4 } & $\begin{array}{c}\text { T I } \\
(\text { Control })\end{array}$ & $\begin{array}{c}\text { T II } \\
\left(50 \mathrm{ppb} \mathrm{AFB}_{1}\right)\end{array}$ & $\begin{array}{c}\text { T III } \\
\left(100 \mathrm{ppb} \mathrm{AFB}_{1}\right)\end{array}$ \\
\hline Tifton hay/Alfalfa (g) & 7.400 & 6.900 & 6.600 \\
Commercial concentrate $(\mathrm{g})$ & 4.000 & 4.000 & 4.000 \\
Mycotoxin concentration $(\mu \mathrm{g})$ & & & \\
Aflatoxin $\mathrm{B}_{1}\left(\mathrm{AFB}_{1}\right)$ & 0 & 50 & 100 \\
Zearalenone $(\mathrm{ZEA})$ & $2.758,1$ & $2.687,5$ & $2.655,2$ \\
Deoxynivalenol (DON) & $21.564,7$ & $20.689,9$ & 20.289 \\
Fumonisins $\mathrm{B}_{1}\left(\mathrm{FB}_{1}\right)$ & 2.240 & 2.240 & 2.240 \\
Total (g) & 11.400 & 10.900 & 10.600
\end{tabular}


Austria) as per the manufacturer's instructions and an aliquot $(200 \mu \mathrm{l})$ was derivatized with $700 \mu \mathrm{l}$ trifluoroacetic acid-acetic acid-water (20:10:70,v/v). The derivatized aflatoxin was quantified by High Performance Liquid Chromatography (HPLC), at the "Laboratório de Micologia e Micotoxinas" of "Universidade Federal de Minas Gerais", following the methodology proposed by Trucksess et al. (1994).

Aflatoxins were quantified by injecting $20 \mu \mathrm{L}$ of extract from each vial into an HPLC system consisting of a JASCO model LC2000 pump (Tokyo, Japan) connected to a JASCO model FP-2020 programmable fluorescence detector and a data module JASCO model 6937-J041A (ChromNAV). Chromatographic separations were performed on a stainless steel, C18 reversed-phase column (Supelcosil $^{\mathrm{TM}} \mathrm{LC}-\mathrm{ABZ}, 150 \times 4.6 \mathrm{~mm}, 5 \mu \mathrm{m}$ particle size) connected to a precolumn (Supelguard ${ }^{\mathrm{TM}} \mathrm{LC}-\mathrm{ABZ}, 20 \times 4.6 \mathrm{~mm}, 5 \mu \mathrm{m}$ particle size). The mobile phase was water:methanol:acetonitrile $(4: 1: 1, \mathrm{v} / \mathrm{v} / \mathrm{v})$ at a flow rate of $1.0 \mathrm{ml} \mathrm{min}^{-1}$. Fluorescence of aflatoxin derivatives was recorded at excitation and emission wavelengths of $\lambda 360 \mathrm{~nm}$ and $\lambda 460 \mathrm{~nm}$, respectively. Standard curves were constructed with different levels of $\mathrm{AFB}_{1}$. This toxin was quantified by correlating peak heights of sample extracts with those of standard curves. The detection limit of the analytical method was $0.4 \mathrm{ng} \mathrm{g}^{-1}$.

The concentration of $\mathrm{AFB}_{1}$ yielded was $4.25 \mathrm{mg} / \mathrm{kg}$ and it was diluted daily in the concentrate feed to obtain the desired concentrations according to the equation: $\mathrm{Ci} \times \mathrm{Vi}=\mathrm{Cf} \times \mathrm{Vf}$, (where $\mathrm{Ci}$ and $\mathrm{Cf}$ are the initial and final concentrations and $\mathrm{Vi}$ and $\mathrm{Vf}$, the initial and final volumes).

Performance evaluation. The performance was assessed through an exercise test at the 21 th day of the experimental stage. The average temperature during the day was $21.5^{\circ} \mathrm{C}$, with a minimum of $12.2^{\circ} \mathrm{C}$ and maximum of $28.1^{\circ} \mathrm{C}$ and the relative humidity was $62.4 \%$. The animals performed standard exercise training for 50 minutes, 5 days per week, during three weeks of the experimental stage. The training program of walking and trotting had been intercalated with flexion movements. For the exercise test, the animals were randomly split into 3 groups with 4 animals each. The test started at 9:00 a.m. and finished at 12:06 a.m. on the same day; they were performed sequentially for each group. The test consisted of a 17 min warm-up of walking and trotting followed by three sets of gallops at a speed of $450 \mathrm{~m} / \mathrm{min}$ for three minutes each. In the intervals between the gallops, the horses were monitored for heart rate (HR), and when the heart rate returned to $60-70 \mathrm{bpm}$ the animals moved on to the next gallop. In order to evaluate the performance of the animals in the test, the heart rate, the respiratory frequency was recorded. Blood samples were taken to analyze the globular volume, glucose, lactate and blood biochemistry. These variables were obtained before the exercise test, and after the third gallop and continued up to 48 hours after the test as described: M0 (Pre-exercise), M1 (Immediately after the exercise test), M2 (10min), M3 (20min), M4 (60min), M5 (3h), M6 (6h), M7 (12h), M8 (24h) and M9 (48h).

Heart rate and respiratory rate were recorded with a stethoscope (Mod LittmannMR). Blood samples were collected using a vacuum collection needle $\left(\mathrm{BD}^{\circledR}\right)$ and vacuum tubes with EDTA (BD Vacutainer ${ }^{\circledR}$ ) for the complete blood count (CBC). Vacuum tubes with sodium fluoride (BD Vacutainer ${ }^{\circledR}$ ) were used to determine glucose and lactate measures and vacuum tubes without anticoagulant (BD Vacutainer ${ }^{\circledR}$ ) were used to obtain blood serum samples, for biochemical determination of enzymatic activity, total proteins and fractions, cholesterol, urea and creatinine measures. After collection, the samples were centrifuged at 7.000rpm for 10 minutes to separate the plasma and serum. Aliquots of both plasma and serum of $1.0 \mathrm{~mL}$ were pipetted automatically and stored at $-20^{\circ} \mathrm{C}$ in $1.5 \mathrm{~mL}$ polypropylene tubes until required for analysis. Subsequently, the analyzes were performed by the enzymatic/colorimetric method in a spectrophotometer SB 190 (CELM ${ }^{\circledR}$ Cia Equipadora de Laboratórios Modernos - CELM. Brazil). Labtest ${ }^{\circledR}$ kits were used for all analyzes.

Statistical analysis. The results were evaluated for normality by Lilliefors test and the homogeneity by Cochran and Bartlett test. Data of the hematological, biochemical and physiological variables were submitted to analysis of variance (ANOVA) in a split-plot scheme with the levels of inclusions of $\mathrm{AFB}_{1}$ in the diets evaluated in the parcels and the exercise test times evaluated in sub-parcels. The means were compared by the Tukey test, at 0.05 significance level, using the Statistical and Genetic Analysis System (SAEG 2007).

\section{RESULTS}

\section{Occurrence of mycotoxins in feedstuffs}

The mycotoxins observed in the feedstuffs of basal diet were: DON, $5.620 \mu \mathrm{g} / \mathrm{kg}$, in Tifton and alfalfa hay and commercial concentrate; ZEA, $708 \mu \mathrm{g} / \mathrm{kg}$, in alfalfa hay and commercial concentrate; and FB1, $560 \mu \mathrm{g} / \mathrm{kg}$, in commercial concentrate. The intake of mycotoxins by the horses according to the treatments are given in Table 2 .

\section{Physiological parameters}

The intake of aflatoxin $B_{1}$ did not affect the respiratory rate (RR) and heart rate (HR) values of horses in the exercise test $(\mathrm{P}>0.05)$, however, there was a simple effect of the time of evaluation $(\mathrm{P}<0.05)$ (Table 3$)$.

\section{Blood and biochemical parameters}

The inclusion of aflatoxin $B_{1}$ in the diets did not affected the blood parameters of the horses in the exercise test, except the enzyme alkaline phosphatase (ALP) (Table 4) $(\mathrm{P}<0.05)$. The globular volume (GV), total protein (TP), albumin (ALB) and cholesterol (COL) were evaluated at M0 through to M3 of the exercise test, and the results have been influenced by the exercise $(\mathrm{P}<0.05)$, with any effect from aflatoxin $\mathrm{B}_{1}$ inclusion to the diets $(\mathrm{P}>0.05)$ (Table 5).

Table 2. Means of the mycotoxin intake per kg of dry matter (Kg DM) and per kg of body weight (kg BW), according to the treatments

\begin{tabular}{cccccccc}
\hline \multirow{2}{*}{ Variables } & \multicolumn{2}{c}{$\begin{array}{c}\text { T I } \\
\text { (Control) }\end{array}$} & \multicolumn{2}{c}{ T II } & \multicolumn{2}{c}{ T III } \\
& & (50 ppb AFB1) & (100 ppb AFB1) \\
\cline { 2 - 8 } & Kg DM & Kg BW & Kg DM & Kg BW & Kg DM & Kg BW \\
\hline \multirow{2}{*}{$\begin{array}{c}\text { Mycotoxins } \\
\text { intake }(\mu \mathrm{g})\end{array}$} & ZEA & 241.1 & 6.1 & 246.7 & 5.7 & 249.3 & 5.9 \\
& DON & 1885.1 & 47.6 & 1899.1 & 43.9 & 1904.7 & 45.3 \\
& FB1 & 195.8 & 4.9 & 205.6 & 4.8 & 210.3 & 5.0
\end{tabular}

Table 3. Respiratory rate and heart rate of horses fed diets with different inclusions of $\mathrm{AFB}_{1}$ and submitted to an exercise test

\begin{tabular}{|c|c|c|c|c|c|}
\hline \multirow{2}{*}{ Variable } & \multirow{2}{*}{ Average } & \multirow{2}{*}{$\begin{array}{l}\mathrm{CV} \\
(\%)\end{array}$} & \multicolumn{3}{|c|}{ Interactions (P Value) } \\
\hline & & & $\mathrm{AFB}_{1}$ & Time & $\mathrm{AFB}_{1} \mathrm{X}$ Time \\
\hline $\begin{array}{l}\text { Respiratory rate } \\
\text { (mov/min) }\end{array}$ & 13.3 & 21.5 & NS & 0.0000 & NS \\
\hline $\begin{array}{l}\text { Heart rate } \\
\text { (beat } / \mathrm{min} \text { ) }\end{array}$ & 66.9 & 16.0 & NS & 0.0000 & NS \\
\hline
\end{tabular}

$\mathrm{CV}=$ Coefficient of variation, $\mathrm{NS}=$ not significant 
The serum concentrations of urea and creatinine were evaluated at many times of the exercise test. The results showed that these parameters were not influenced by the aflatoxin $\mathrm{B}_{1}$ inclusion in the diets $(\mathrm{P}>0.05)$. However, a simple effect of the exercise test was observed (Table 6).

The enzymes aspartate transferase (AST), lactate desidrogenase (LDH) and gama glutamil transferase (GGT) activities were evaluated from M0 to M9 of the exercise test, while the enzyme creatine quinase (CK) was evaluated from M0 to M7 of the exercise test. The activities of the enzymes were not affected by aflatoxin $B_{1}$ inclusion to the diets $(P>0.05)$. However, the AST, LDH, GGT and CK activities were influenced by the exercise $(\mathrm{P}<0.05)$ (Table 7$)$. The alkaline phosphatase (ALP) activity was affected by the inclusion of aflatoxin in the diets $(\mathrm{P}<0.05)$, presenting a higher value in horses fed diet with $100 \mu \mathrm{g} / \mathrm{kg}$ of $\mathrm{AFB}_{1}$, (Table 8).

Table 4. Hematological and blood biochemistry of horses fed diets with different inclusions of AFB ${ }_{1}$ and submitted to an exercise test

\begin{tabular}{|c|c|c|c|c|c|c|}
\hline \multirow{2}{*}{ Variable } & \multirow{2}{*}{ Average } & \multirow{2}{*}{ CV (\%) } & \multicolumn{3}{|c|}{ Interactions (P Value) } & \multirow{2}{*}{ Reference values } \\
\hline & & & $\mathrm{AFB}_{1}$ & Time & $\mathrm{AFB}_{1} \mathrm{X}$ Time & \\
\hline Globular Volume (\%) & 39.8 & 5.5 & NS & 0.0000 & 0.1709 & $38-42^{\mathrm{A}}$ \\
\hline Total protein $\left(\mathrm{gdL}^{-1}\right)$ & 6.2 & 16.8 & NS & 0.0003 & NS & $5.2-7.9^{\mathrm{C}}$ \\
\hline Albumins $\left(\mathrm{g} \mathrm{dL}^{-1}\right)$ & 2.4 & 17.1 & NS & 0.0001 & 0.2319 & $2.6-3.7^{\mathrm{C}}$ \\
\hline Cholesterol (mg dL $\left.{ }^{-1}\right)$ & 97.4 & 16.1 & NS & 0.0014 & 0.4034 & $75-150^{\text {в }}$ \\
\hline Urea $\left(\mathrm{mg} \mathrm{dL}^{-1}\right)$ & 33.4 & 10.4 & NS & 0.0000 & 0.4247 & $24-48^{\mathrm{A}}$ \\
\hline Creatinine $\left(\mathrm{mg} \mathrm{dL}^{-1}\right)$ & 0.74 & 10.5 & NS & 0.0000 & NS & $1.1-1.8^{\mathrm{A}}$ \\
\hline GGT $\left(U^{-1}\right)$ & 7.8 & 38.5 & NS & 0.0000 & 0.1161 & $4.3-13^{\mathrm{E}}$ \\
\hline $\operatorname{AST}\left(\mathrm{U} \mathrm{L}^{-1}\right)$ & 271.3 & 16.3 & 0.0671 & 0.0000 & 0.1279 & $150-400^{A}$ \\
\hline $\mathrm{CK}\left(\mathrm{U} \mathrm{L}^{-1}\right)$ & 323.7 & 27.8 & 0.3226 & 0.0000 & NS & $100-300^{\mathrm{A}}$ \\
\hline $\mathrm{LDH}\left(\mathrm{U} \mathrm{L}^{-1}\right)$ & 936.3 & 36.5 & 0.2882 & 0.000 & NS & $162-412^{\mathrm{C}}$ \\
\hline $\operatorname{ALP}\left(U^{-1}\right)$ & 61.4 & 18.5 & 0.0227 & 0.3679 & 0.3625 & $100-500^{\mathrm{D}}$ \\
\hline Glucose (mg dL $\left.{ }^{-1}\right)$ & 74.8 & 20.2 & NS & 0.0000 & NS & $70-140^{\mathrm{A}}$ \\
\hline Lactate $\left(\mathrm{mmol} \mathrm{L}^{-1}\right)$ & 1.8 & 19.6 & 0.927 & 0.0000 & NS & $1,1-1,8^{\mathrm{F}}$ \\
\hline
\end{tabular}

Table 5. Mean values of Globular volume (\%), Total protein $\left(\mathrm{g} \mathrm{dL}^{-1}\right)$, Albumins $\left(\mathrm{g} \mathrm{dL}^{-1}\right)$ and Cholesterol (mg dL $\left.\mathrm{dL}^{-1}\right)$ in horses fed diets with different inclusions of $\mathrm{AFB}_{1}$ and submitted to an exercise test

\begin{tabular}{|c|c|c|c|c|c|}
\hline \multirow[b]{2}{*}{ Variable } & \multicolumn{4}{|c|}{ Exercise test evaluation times } & \multirow[b]{2}{*}{$\mathrm{CV}(\%)$} \\
\hline & Pre-exercise & $\begin{array}{c}\text { Immediately after the } \\
\text { exercise test }\end{array}$ & $10 \mathrm{~min}$ & $20 \mathrm{~min}$ & \\
\hline Globular volume (\%) & $34.2^{\mathrm{D}}$ & $47.6^{\mathrm{A}}$ & $39.9^{B}$ & $37.4^{\mathrm{C}}$ & 5.5 \\
\hline Total protein $\left(\mathrm{g} \mathrm{dL}^{-1}\right)$ & $4.9^{\mathrm{B}}$ & $7.0^{\mathrm{A}}$ & $6.6^{\mathrm{A}}$ & $6.4^{\mathrm{A}}$ & 16.8 \\
\hline Albumins $\left(\mathrm{g} \mathrm{dL}^{-1}\right)$ & $1.9^{\mathrm{B}}$ & $2.8^{\mathrm{A}}$ & $2.5^{\mathrm{A}}$ & $2.6^{\mathrm{A}}$ & 17.1 \\
\hline Cholesterol $\left(\mathrm{mg} \mathrm{dL}^{-1}\right)$ & $81.4^{\mathrm{B}}$ & $109.5^{\mathrm{A}}$ & $96.7^{\mathrm{AB}}$ & $101.8^{\mathrm{A}}$ & 16.1 \\
\hline
\end{tabular}

Table 6. Serum concentrations of urea and creatinine ( $\mathrm{mg} \mathrm{dL-1}$ ) in horses fed diets with different inclusions of $\mathrm{AFB}_{1}$ and submitted to an exercise test

\begin{tabular}{|c|c|c|c|c|c|c|c|c|c|c|c|}
\hline \multirow{2}{*}{ Variable } & \multicolumn{10}{|c|}{ Exercise test evaluation times } & \multirow{2}{*}{$\mathrm{CV} \%$} \\
\hline & MO & M1 & M2 & M3 & M4 & M5 & M6 & M7 & M8 & M9 & \\
\hline Urea $\left(\mathrm{mg} \mathrm{dL}^{-1}\right)$ & $37.5^{\mathrm{AB}}$ & $36.2^{\mathrm{BC}}$ & $28.8^{\mathrm{EF}}$ & $30.0^{\mathrm{DEF}}$ & $32.1^{\mathrm{AB}}$ & $30.2^{\mathrm{DEF}}$ & $33.4^{\mathrm{BCD}}$ & $37.1^{\mathrm{AB}}$ & $42.6^{\mathrm{A}}$ & $26.2^{\mathrm{F}}$ & 10.4 \\
\hline Creatinine (mg dL ${ }^{-1}$ ) & $1.4^{\mathrm{A}}$ & $0.7^{\mathrm{B}}$ & $0.7^{\mathrm{B}}$ & $0.7^{\mathrm{B}}$ & $0.5^{\mathrm{D}}$ & $0.6^{\mathrm{CD}}$ & $0.7^{\mathrm{B}}$ & $0.8^{\mathrm{B}}$ & $0.7^{\mathrm{BC}}$ & $0.5^{\mathrm{D}}$ & 10.5 \\
\hline
\end{tabular}

$\mathrm{CV}=$ Coefficient of variation; ${ }^{\mathrm{A}, \mathrm{B}, \mathrm{C}, \mathrm{D}, \mathrm{E}, \mathrm{F}}$ Values followed by same letter in the line do not differ by the Tukey test $(\mathrm{P}>0.05)$.

Table 7. Activity of CK, AST, LDH, GGT (UL ${ }^{-1}$ ) in horses fed diets with different inclusions of AFB ${ }_{1}$ and submitted to an exercise test

\begin{tabular}{|c|c|c|c|c|c|c|c|c|c|c|c|}
\hline \multirow{2}{*}{ Variable } & \multicolumn{10}{|c|}{ Exercise test evaluation times } & \multirow{2}{*}{$\mathrm{CV} \%$} \\
\hline & MO & M1 & M2 & M3 & M4 & M5 & M6 & M7 & M8 & M9 & \\
\hline $\mathrm{CK}\left(\mathrm{UL}^{-1}\right)$ & $328.4^{\mathrm{BC}}$ & $288.5^{\mathrm{C}}$ & $343.3^{\mathrm{BC}}$ & $484.2^{\mathrm{A}}$ & $399.9^{\mathrm{AB}}$ & $296.5^{C}$ & $308.7^{\mathrm{BC}}$ & $139.7^{\mathrm{D}}$ & - & - & 27.8 \\
\hline $\operatorname{AST}\left(\mathrm{UL}^{-1}\right)$ & $291.7^{\mathrm{ABC}}$ & $326.6^{A}$ & $245.6^{\mathrm{CD}}$ & $255.9^{\mathrm{BCD}}$ & $268.6^{\mathrm{ABC}}$ & $209.2^{\mathrm{D}}$ & $292.3^{\mathrm{ABC}}$ & $311.4^{\mathrm{AB}}$ & $304.2^{\mathrm{ABC}}$ & $207.5^{\mathrm{D}}$ & 16.4 \\
\hline $\mathrm{LDH}\left(\mathrm{UL}^{-1}\right)$ & $932.0^{\mathrm{ABC}}$ & $750.2^{\mathrm{BC}}$ & $733.9^{\mathrm{BC}}$ & $693.9^{\mathrm{C}}$ & $1169.8^{\mathrm{AB}}$ & $806.2^{\mathrm{ABC}}$ & $938.7^{\mathrm{ABC}}$ & $1257.4^{\mathrm{A}}$ & $1156.5^{\mathrm{A}}$ & $823.9^{\mathrm{ABC}}$ & 36.5 \\
\hline GGT $\left(\mathrm{UL}^{-1}\right)$ & $6.2^{\mathrm{CD}}$ & $7.2^{\mathrm{BCD}}$ & $7.2^{\mathrm{BCD}}$ & $6.2^{\mathrm{CD}}$ & $9.6^{\mathrm{AB}}$ & $7.8^{\mathrm{BC}}$ & $7.3^{\mathrm{BCD}}$ & $9.7^{\mathrm{AB}}$ & $11.8^{\mathrm{A}}$ & $5.0^{\mathrm{D}}$ & 38.5 \\
\hline
\end{tabular}

$\mathrm{CV}=$ Coefficient of variation; ${ }^{\mathrm{A}, \mathrm{B}, \mathrm{C}, \mathrm{D}}$ Values followed by same letter in a row do not differ by the Tukey test $(\mathrm{P}>0.05)$. 
Table 8. Alkaline phosphatase activity $\left(\mathrm{UL}^{-1}\right)$ in horses fed diets with different inclusions of $\mathrm{AFB}_{1}$ and submitted to an exercise test

\begin{tabular}{|c|c|c|c|c|c|c|c|c|}
\hline \multirow{2}{*}{ Treatment } & \multicolumn{4}{|c|}{ Exercise test evaluation times } & \multirow{2}{*}{ Average } & \multicolumn{3}{|c|}{ Interactions (P Value) } \\
\hline & M0 & M1 & M2 & M3 & & $\mathrm{AFB}_{1}$ & Time & $\mathrm{AFB}_{1}$ time \\
\hline T I (Control) & 65.3 & 49.8 & 44.5 & 47.5 & $51.8^{\mathrm{B}}$ & & & \\
\hline T II (50 ppb AFB $)$ & 55.5 & 56.5 & 59.0 & 54.0 & $56.3^{\mathrm{AB}}$ & 0.0227 & 0.3679 & 0.3625 \\
\hline T III (100 ppb AFB $)$ & 75.8 & 82.5 & 75.0 & 72.0 & $76.3^{A}$ & & & \\
\hline
\end{tabular}

Coefficient of variation $(\mathrm{CV})=18,5 \%{ }^{\mathrm{A}, \mathrm{B}}$ Values followed by same letter in a column do not differ by the Tukey test $(\mathrm{P}>0.05)$.

Table 9. Glucose (mg dL-1) and Lactate (mmol dL-1) concentrations in horses fed diets with different inclusions of AFB ${ }_{1}$ and submitted to an exercise test

\begin{tabular}{lccccccccccc}
\hline \multirow{2}{*}{ Variable } & \multicolumn{9}{c}{ Exercise test evaluation times } & \multicolumn{1}{c}{ CV \% } \\
\cline { 2 - 7 } & M0 & M1 & M2 & M3 & M4 & M5 & M5 & M7 & M8 & M9 \\
\hline $\begin{array}{l}\text { Glucose } \\
\left(\mathrm{mg} \mathrm{dL}^{-1}\right)\end{array}$ & $99.0^{\mathrm{A}}$ & $57.3^{\mathrm{E}}$ & $66.2^{\mathrm{DE}}$ & $67.83^{\mathrm{DE}}$ & $76.2^{\mathrm{ABCD}}$ & $63.6^{\mathrm{DE}}$ & $71.4^{\mathrm{BCDE}}$ & $89.6^{\mathrm{AB}}$ & $87.9^{\mathrm{ABC}}$ & $68.6^{\mathrm{CDE}}$ & 20.2 \\
$\begin{array}{l}\text { Lactate } \\
\left(\mathrm{mmol} \mathrm{dL}^{-1}\right)\end{array}$ & $0.92^{\mathrm{C}}$ & $3.2^{\mathrm{A}}$ & $1.77^{\mathrm{B}}$ & $1.76^{\mathrm{B}}$ & $1.48^{\mathrm{B}}$ & $1.43^{\mathrm{B}}$ & $1.76^{\mathrm{B}}$ & - & - & - & 19.6
\end{tabular}

$\overline{\mathrm{CV}}=$ Coefficient of variation; ${ }^{\mathrm{A}, \mathrm{B}, \mathrm{C}, \mathrm{D}, \mathrm{E}}$ Values followed by at same letter in a line do not differ by the Tukey test $(\mathrm{P}>0.05)$.

The serum concentration of glucose was evaluated from M0 to M9 of the exercise test, while the lactate concentration was evaluated from M0 to M7 of the exercise test. Serum glucose and lactate concentrations were not influenced by the inclusion of aflatoxin $B_{1}$ in the diets $(P>0.05)$ (Table 9).

\section{DISCUSSION}

The $\mathrm{AFB}_{1}$ was not detected in the feedstuffs of the basal diet. The $\mathrm{AFB}_{1}$ produced in our laboratory and added to the commercial concentrate at concentrations of $50 \mu \mathrm{g} / \mathrm{kg}$ and $100 \mu \mathrm{g} / \mathrm{kg}$, according to the treatments, which was the maximum amount intake by the horses, regardless of weight. Keller et al. (2007) observed in horse's feedstuffs concentrations of $\mathrm{AFB}_{1}$ ranging from 0.01 to $99.4 \mu \mathrm{g} / \mathrm{kg}$. Franco et al. (2019) observed in maize food and maize-based feed from smallscale farms that median levels of total AF, total FB, ZEN, and DON were $100 \mu \mathrm{g} / \mathrm{kg}, 680 \mu \mathrm{g} / \mathrm{kg}, 160 \mu \mathrm{g} / \mathrm{kg}$, and $200 \mu \mathrm{g} / \mathrm{kg}$, in feed samples, respectively, and that co-occurrence of two or more mycotoxins was confirmed in $51 \%$ of feed samples.

Caloni \& Cortinovis (2011) in a review of experimental AFB intoxication in horses reported that, although inconclusive, aflatoxicosis can occur with $\mathrm{AFB}_{1}$ concentrations between 0.5 and $1.0 \mathrm{mg} / \mathrm{kg}$ in the diet, which induce clinical signals and hepatic damages, depending on the exposure time. The liver is a target organ in all affected animals, where the toxin induces centrilobular necrosis. Horses with aflatoxicosis show nonspecific clinical signs, such as cough, inappetence, depression, fever, tremor and ataxia. However, the blood and physiological alterations of horses in this research are resulting from the exercise test itself, with no effects from aflatoxin, except for the alkaline phosphatase activity. Dedar et al. (2019) observed growth retardation in foals, weight loss and deaths in horses ingesting millet forage contaminated with levels of $24 \mu \mathrm{g}$ of aflatoxins $/ \mathrm{kg}$ to $70 \mu \mathrm{g}$ of aflatoxins $/ \mathrm{kg}$ of forage. For the authors, monitoring serum/plasma GGT levels was found to be a sensitive biochemical indicator to identify liver damage caused by mycotoxins. The daily intake of horses of diet in treatment III $\left(100 \mu \mathrm{g} / \mathrm{kg}\right.$ of $\left.\mathrm{AFB}_{1}\right)$, corresponding a $9.4 \mu \mathrm{g} \mathrm{AFB}$ by $\mathrm{kg} \mathrm{DM}$, did not result in any clinical signs in the horses.
The simultaneous occurrence of DON, ZEA and FB in the feedstuffs of basal diet is related to the 25 to $30 \%$ of corn in the diet. The concentration of mycotoxins in feedstuffs for horses is a serious problem, and the weather in Brazil is favorable to fungi multiplication and mycotoxins production (Keller et al. 2007, Schulz et al. 2015). Schumann et al. (2016) and Franco et al. (2019) pointed out that the simultaneous occurrence of Fusarium mycotoxins, such as DON and ZEA, is an important issue to be observed due to its implications on animal health and welfare.

The concentration of DON in the basal diet was $5.6 \mathrm{mg} /$ $\mathrm{kg}$, with similar concentrations in alfafa hay and in the concentrate. Caloni \& Cortinovis (2011) and Cortinovis et al. (2012) observed that horses fed naturally DON contaminated barley between 36 and $44 \mathrm{mg} / \mathrm{kg}$ during 40 days they did not show any negative effects, such as refusing feed or alteration of blood biochemistry and hematology, suggesting that like ruminants, horses are relatively resistant to the adverse effects of DON.

The ZEA concentration in feedstuffs were $446.5 \mu \mathrm{g} / \mathrm{kg}$ and $261.5 \mu \mathrm{g} / \mathrm{kg}$ for concentrate and alfafa, respectively. Gimeno \& Quintanilla (1983) reported natural outbreaks from feedstuffs containing approximately $2.7 \mathrm{mg} / \mathrm{kg}$ of ZEA in horses. Intoxicated mares refused the diet, and presented vulvar edema, vaginal prolapse and internal hemorrhage, and severe sagging of the genitalia. In this research, no clinical symptoms were observed in the horses, suggesting that the amount of ZEA present in the basal diet was not enough to cause clinical alterations. It should be noted that the concentration of ZEA was lower than the European Union (2006) of 3mg/ $\mathrm{kg}$ for corn by-products.

The $\mathrm{FB}_{1}$ concentration in feedstuffs was $560 \mu \mathrm{g} / \mathrm{kg}$. Horses are the most sensitive specie to FB1 toxicity, and FB concentrations of $20 \mu \mathrm{g} / \mathrm{kg}$ and $120 \mu \mathrm{g} / \mathrm{kg}$ in feed are already able to cause outbreak in this specie (Bertero et al. 2018). Ross et al. (1991) analyzed feedstuffs associated with an equine leukoencephalomalacea outbreaks observed contamination with $\mathrm{FB}_{1}$ with levels ranging from 1 to $126 \mathrm{mg} / \mathrm{kg}$. Most samples presented levels above $10 \mathrm{mg} / \mathrm{kg}$. According to Reed et al. (2004) feedstuffs containing concentrations greater than 
$10 \mathrm{mg} / \mathrm{kg}$ of fumonisin are fatal to horses. In this research, no clinical signs compatible with equine leukoencephalomalacea were observed, however the hematological and enzymatic alterations should be evaluated as they may be related to the simultaneous presence of several mycotoxins, especially aflatoxin $\mathrm{B}_{1}$.

The physiological parameters Respiratory rate (RR) and Heart rate (HR) were evaluated at pre-exercise (M0), immediately after the exercise (M1) and at the times of 10 (M2) and 20 minutes after exercise (M3) (Table 3). There were no effects of $\mathrm{AFB}_{1}$ inclusion in the diets in the respiratory (RR) and heart rate $(\mathrm{HR})$ of the horses $(\mathrm{P}>0.05)$. The results showed the response of horses to exercise, with an increase of both RR and HR immediately after exercise (M1), and with a tendency to return to basal levels at $20 \mathrm{~min}$ (M3) after exercise. The values differed from those observed by Paludo et al. (2002) for Brazilian Sport Horses that showed mean values of heart rates of $40.8 \pm 4.7$, and respiratory rate of $16.7 \pm 3.1$, in the pre-exercise and of $53.7 \pm 8.2$ and $37.3 \pm 11.5$, for heart and respiratory rates, respectively, in the post-exercise period.

The inclusion of $\mathrm{AFB}_{1}$ in the diets did not affected the blood parameters (Table 4), except for the alkaline phosphatase activity. The presence of aflatoxin together with other mycotoxins, especially FB, could be expected to cause changes in the blood profile during exercise due to hepatotoxicity. The intake of low doses of mycotoxins for long periods can influence the health and the performance of horses (Raymond et al. 2005, Broom 2015). Thus, hepatotoxic mycotoxins could be expected to impair hepatic metabolism, influencing the results of this research. However, the alterations observed were those resulting from the exercises on the horse, as a simple effect of time, with no effect to $\mathrm{AFB}_{1}$ in the diets.

As expected, immediately after exercise (M1), the Globular volume presented a higher value; about 39\% higher than the baseline value. The elevation of globular volume is related to spleen contraction. According to Kingston (2008) and McGowan (2008) the spleen has the capacity to store about $50 \%$ of the body's erythrocytes in horses. The release of the erythrocytes in the body occurs in response to sympathetic stimulation or increased circulation of adrenaline during exercise. The values for total protein and albumin in response to exercise were not influenced by the inclusion of $\mathrm{AFB}_{1}$ in the diets, and only a simple effect of time was observed $(\mathrm{P}<0.05)$.

The increase of protein concentration immediately after exercise was observed, and its remained for 10 and 20 minutes (M3 and M4) as a consequence of blood concentration, redistribution of fluids and electrolytes from the vascular compartment to the extracellular spaces, and increased plasma viscosity (Kingston 2008). Fluid loss is related to the duration and intensity of exercise and returns to basal levels within 30 minutes of the exercise (Kowal et al. 2006). Cholesterol plasma concentration was not influenced by $\mathrm{AFB}_{1}$ inclusion in the diets $(\mathrm{P}>0.05)$. The highest concentration of cholesterol immediately after exercise may be due to the increase in plasma viscosity arising from blood concentration (Kingston 2008). However, the values observed are within the reference levels for horses (Gonzalez \& Silva 2006).

Plasma levels of urea and creatinine were evaluated during 48 hours post exercise (M0 to M9). As expected, the urea levels were little influenced by exercise. Snow et al. (1982) stated that the main route of energy generation used by horses is glycolytic and anaerobic, compatible with the exercise test in the experiment: warm-up followed by three sets of gallops at a speed of $450 \mathrm{~m} / \mathrm{min}$ for three minutes each. Also, changes in urea concentration over time may be due to the catabolism of nitrogen from the diets. On the other hand, the serum creatinine concentrations during exercise were lower than the baseline value, which was not expected. According to Fazio et al. (2011) there is an increase in plasma creatinine concentrations during exercise due to the greater use of phosphocreatine for the generation of muscular energy. Castejón et al. (2006) observed that this increase is directly proportional to the intensity of the exercise. The values of creatinine concentration in this work were below those observed by Santiago et al. (2013) evaluating eventing horses at training, and Godoi et al. (2009) who evaluated eventing horses feeding hyperlipidemic diets. The values of urea and creatinine concentrations were below the reference values for the horses according to Rose \& Hodgson (1994).

The peak of CK activity was observed at 20 minutes after exercise (M3), with a tendency to return to baseline three hours after the exercise (M5). Harris et al. (1990) reported that some animals may have high physiological enzymatic levels of $\mathrm{CK}$, or even that these enzymes are removed more slowly from the circulation, or some animals may be more sensitive as to the permeability of the cellular muscular membrane compared to a similar stimulus in other animals. According to Sloet van Oldruitenborgh-Oosterbaan (1998), the plasma half-life of CK is very short, around 2 hours, which is compatible with the results observed in this experiment. The mean values of CK were higher than those observed by Oliveira et al. (2014) in Brazilian Sport Horses on treadmill exercise tests, but result of CK 12 hours after exercise (M7) was similar those found by Padilha et al. (2017) in the same breed, a 48-h rest by training.

The AST serum activity shows a standard exercise profile (Thomassian et al. 2007). The peak of AST activity was observed immediately after exercise (M1) and a tendency to increase 6 hours post exercise (M6). The high concentrations of AST immediately after exercise are related to the physiological process of fluid transfer to the extravascular space during exercise, increasing the AST activity in plasma, with a return to the 30-minute-baseline (Kingston 2008). The results of AST 48 h post exercise (M9) are very similar to those found by Padilha et al. (2017) in adult Brazilian sport horses a 48-h rest after training.

Differently from AST, the LDH activity did not present a standard profile in response to exercise, and the LDH peak was observed 12 hours post exercise (M7). The results observed were higher than the values reported by Oliveira et al. (2014) in horses on treadmill exercise tests. The large variation of LDH plasma activity can be explained by the distribution of this enzyme in several different tissues. The values of LDH plasma activity refer to the sum of several isoenzymes, so the interpretation of elevated LDH values may be compromised (Harris et al. 1990). In addition, non-pathological states may also cause increase in AST activity like LDH, as well as the collection methods, processing and equipment used for the analyzes (Sloet van Oldruitenborgh-Oosterbaan M. 1998, Thomassian et al. 2007).

The GGT activity was not influenced by the inclusion of $\mathrm{AFB}_{1}$ in the diets $(\mathrm{P}>0.05)$. The increase of the enzyme is 
indicative of liver damage, cholestasis and proliferation of bile ducts in all animal species (Kerr 2002, Kingston 2008, Dedar et al. 2019). Horses submitted to exercise conditioning for a prolonged period may present an increase of GGT (Balarin et al. 2005). In this experiment, the GGT activity had a peak at about 60 minutes after exercise (M4), oscillating for up to 24 hours (M8). The pre-exercise physical training period in this work during three weeks, was very short, when compared with the 12 months of training cited by Balarin et al. (2005). However, the values observed are within the basal levels for horses, ranging from 4.3 to $13 \mathrm{UL}^{-1}$ (Thomassian 2005).

The Alkaline phosphatase (ALP) activity was affected by the $\mathrm{AFB}_{1}$ inclusion in the diets $(\mathrm{P}<0.05)$, and ALP activity increased in horses fed diet with the $100 \mu \mathrm{g} / \mathrm{kg}$ of $\mathrm{AFB}_{1}$. ALP is an enzyme widely distributed in the body, and the hepatic isoform predominates in the serum, and the higher values of ALP activity is indicative of liver damage in horses (Kerr 2002). Kingston (2008) reported ALP increases in horse serum due to prolonged exercise; however, it is not clear whether this increase is from bone or hepatic origin. Hank et al. (1993) observed that about $17.9 \%$ of serum ALP in mature horses is from the bones. Trueman et al. (1983) stated that increases in ALP are often unexplained and that concentrations between $0-599 I U / L$ can be considered normal. In this work, the horses were submitted to exercise conditioning during three weeks and the ALP activity in horses fed diet with $50 \mu \mathrm{g} / \mathrm{kg}$ of AFB was higher than ALP activity in horses fed basal diet. The ALP activity in horses fed diet with $100 \mu \mathrm{g} / \mathrm{kg}$ of $\mathrm{AFB}_{1}$ was higher than the ALP activity in horses feeding the other two diets. All the animals were submitted the same exercise intensity, and ALP was monitored up to 20 minutes after the test (M3).

Liver damage and gastrointestinal disorders may occur in horses feeding diets containing from 2 to $50 \mu \mathrm{g} / \mathrm{kg}$ of $\mathrm{AFB}_{1}$ (Reed et al. 2004). Kaneko et al. (2008) reported that chronic intoxication of pigs with fumonisins is associated with increases of ALP, AST and GGT. Thus, the potential interaction and synergism of $\mathrm{AFB}_{1}$ with $\mathrm{FB}_{1}$ (CAST 2003) which may have influenced the ALP results and should be considered. Thus, it appears that the results of ALP activity were from hepatic tissue and its activity is directly influenced by the increased $\mathrm{AFB}_{1}$ concentration of the diets. However, the results observed are within the clinical values considered normal for the horses, according to Trueman et al. (1983).

The serum glucose and lactate concentrations (Table 9) were not affected by the $\mathrm{AFB}_{1}$ inclusion in the diets $(\mathrm{P}>0.05)$. Glucose and lactate concentrations reflect the energy metabolism and performance. The mycotoxins were expected to affect the hepatic metabolism and animal response to exercise since the liver plays a central role in metabolism, synthesizing and distributing nutrients to the peripheral organs through blood circulation (Gonzalez \& Silva 2006), however, did not occur. Higher glucose concentration was observed during the rest period (pre-exercise). According to Kerr (2002), the glucose concentration increases during exercises due to the adrenaline. In this work, a decrease in glucose levels was observed, which glucose levels were restored after feeding. According to Pösö et al. (2004), changes in glucose concentration depend on the type of exercise, and may increase or decrease in short-term exercises. The serum values for glucose in this work were higher than those observed by Santiago et al. (2013) in eventing horses in the initial phase of training as observed up to the moment M4. However, the glucose values reported here are within the serum levels of the horses (Rose \& Hodgson 1994).

The peak in lactate concentration occurred immediately after exercise (M1). Lactate is an intermediate product of the metabolism of carbohydrates during anaerobic glycolysis. Under anaerobic conditions, such as in intense or prolonged physical activity, pyruvic acid is converted to lactic acid, in a reaction mediated by the Lactate dehydrogenase (Kaneko et al. 2008). The time to return lactate concentration to a baseline is a measure of the fitness of horses (Evans et al. 1995). The values observed in this study are similar to those observed by Santiago et al. (2013) working with horses that were beginners in eventing training.

\section{CONCLUSION}

The mycotoxins in the diets during 28 days doesn't influence the physiological, hematological and blood biochemical responses of the horses, except for the alkaline phosphatase activity, which presented higher activity in the diet with $100 \mu \mathrm{g} / \mathrm{kg}$ of $\mathrm{AFB}_{1}$, suggesting a hepatotoxic action and synergistic effect with the others mycotoxins naturally present in the feedstuffs.

Acknowledgements.- The authors are grateful to the "Fundação de Amparo à Pesquisa do Estado do Rio de Janeiro" (FAPERJ). To the members of the research team of "Laboratório de Pesquisa em Saúde Eqüina” (EQUILAB). To the members of the "Escola de Sargentos das Armas" (ESA), especially to the Cavalry Section, Veterinary and Clinical Laboratory areas due to their unconditional support in the accomplishment of this research.

Conflict of interest statement.- The authors have no competing interests.

\section{REFERENCES}

Balarin M.R.S., Lopes R.S., Kohayagawa A., Laposy C.B. \& Fonteque J.H. 2005 Avaliação da glicemia e da atividade sérica da aspartato aminotransferase, creatinoquinase, gama-glutamiltransferase e lactato desidrogenase em equinos puro sangue inglês (PSI) submetidos a exercício de diferentes intensidades. Semina, Ciênc. Agrárias, 26(2):211-218.

Baldissera M.A., Santurio J.M., Canto S.H., Pranke P.H., Almeida C.A.A. \& Schimidt C. 1993. Aflatoxinas, ocratoxina e zearalenona em alimentos para consumo animal no sul do Brasil - Parte II. Revta Instituto Adolfo Lutz 53(1/2):5-10.

Bertero A., Moretti A., Spicer L.J. \& Caloni F. 2018. Fusarium molds and mycotoxins: potential species-specific effects. Toxins 10(6):244. <http:// dx.doi.org/103390/toxins10060244><PMid:29914090>

Brasil 1988. Portaria MA/SNAD/SFA no 07, de 09/11/88. Diário Oficial da União Seção I, Ministério da Agricultura, Pecuária e Abastecimento (MAPA), Brasília, DF, p.21.968.

Broom L. 2015. Mycotoxins and the intestine. Anim. Nutr. 1(4):262-265. <http://dx.doi.org/10.1016/j.aninu.2015.11.001>

Caloni F. \& Cortinovis C. 2011. Toxicological effects of aflatoxins in horses. Vet. J. 188(3):270-273. <http://dx.doi.org/10.1016/j.tvjl.2010.06.002> <PMid:20619706>

CAST 2003. Mycotoxins: risks in plant, animal and human systems. Report no. 139, Council for Agricultural Science and Technology (CAST), Ames, IA.

Castejón F., Rubio M.D., Agüera E.I., Escribano B.M., Requena F. \& Vivo R. 2007. Respuesta hematológica y plasmática al ejercicio en cinta rodante, p.169-196. In: López G.E.V. (Ed.), Valoración Morfofuncional e la Selección de Reproductores del Caballo de Pura Raza Española. Caja Rural, Córdoba. 
Cortinovis C., Battini M. \& Caloni F. 2012. Deoxynivalenol and T-2 Toxin in raw feeds for horses. J. Equine Vet. Sci. 32(2):72-74. (Short Communication). <http://dx.doi.org/10.1016/j.jevs.2011.08.002>

Dedar R.K., Virmani N., Bala P.A., Singh J., Vaid R.K., Legha R.A. \& Tripathi B.N. 2019. Clinicopathological findings of an episode of mycotoxicosis in horses. Equine Vet. Educ. 31(5):236-241. <http://dx.doi.org/10.1111/eve.12856>

European Union 2006. Recomendação da Comissão, de 17 de agosto de 2006, sobre a presença de desoxinivalenol, zearalenona, ocratoxina A, toxinas T-2 e HT-2 e fumonisinas em produtos destinados à alimentação animal. Off. J. Eur. Union L229:7-9.

Evans D.L., Rainger J.E., Hodgson D.R., Eaton M.D. \& Rose R.J. 1995. The effects of intensity and duration of training on blood lactate concentrations during and after exercise. Equine Vet. J. 27(supl.18):422-425. http://dx.doi. org/10.1111/j.2042-3306.1995.tb04965.x

Fazio F., Assenza A., Tosto F., Casella S., Piccione G. \& Caola G. 2011. Training and haematochemical profile in thoroughbreds and standardbreds: a longitudinal study. Livest. Sci. 141(2/3):221-226. <http://dx.doi. org/10.1016/j.livsci.2011.06.005>

Franco L.T., Petta T., Rottinghaus G.E., Bordin K., Gomes G.A. \& Oliveira C.A.F. 2019. Co-occurrence of mycotoxins in maize food and maize-based feed from small-scale farms in Brazil: a pilot study. Mycotoxin Res. 35(1):65-73. <http://dx.doi.org/10.1007/s12550-018-0331-4><PMid:30242616>

Gimeno A. \& Quintanilla J.A. 1983. Analytical and mycological study of a natural outbreak of Zearalenone mycotoxicosis in horses. Proceedings of the International Symposium of Mycotoxins, Cairo, p.387-392.

Godoi F.N., Almeida F.Q., Guarienti G.A., Santiago J.M., Júnior D.G., Nogueira Y.C. \& Brasileiro L.S. 2009. Perfil hematológico e características das fezes de equino consumindo dietas hiperlipidêmicas. Ciência Rural 39(9):25712577. <http://dx.doi.org/10.1590/S0103-84782009000900029>

Gonzalez F.H.D. \& Silva S.C. 2006. Introdução a Bioquímica Clínica Veterinária. $2^{\text {a }}$ ed. Editora UFRGS, Porto Alegre, 364p.

Hank A.M., Hoffmann W.E., Sanecki R.K., Schaeffer D.J. \& Dorner J.L. 1993. Quantitative determination of equine alkaline phosphatase lsoenzymes in foal and adult serum. J. Vet. Intern. Med. 7(1):20-24. <http://dx.doi. org/10.1111/j.1939-1676.1993.tb03164.x>

Harris P.A., Snow D.H., Greet T.R. \& Rossdale P.D. 1990. Some factors influencing plasma AST/CK activities in Thoroughbred racehorses. Equine Vet. J. 9:66-71. <http://dx.doi.org/10.1111/j.2042-3306.1990.tb04738.x> <PMid:9259810>

Kaneko J.J., Harvey J.W. \& Bruss M.L. 2008. Clinical Biochemistry of Domestic Animals. 6th ed. San Diego, Academic Press, 932p.

Keller K.M., Queiroz B.D., Keller L.A.M., Ribeiro J.M.M., Cavaglieri L.R., GonzálezPereyra M.L., Dalcero A.M. \& Rosa C.A.R. 2007. The mycobiota and toxicity of equines feeds. Vet. Res. Commun. 31(8):1037-1045. <http://dx.doi. org/10.1007/s11259-007-0028-1><PMid:17285246>

Kerr M.M. 2002. Veterinary Laboratory Medicine. 2ª ed. Blackwell Science Ltd., Oxford, 392p.

Kingston J.K. 2008. Hematologic and serum biochemical responses to exercise and training, p.939-948. In: Hinchcliff K.W., Kaneps A.J., Geor R.J. (Eds), Equine Exercise Physiology: the science of exercise on athletic horse. Philadelphia Saunders, Philadelphia.

Kowal R.J., Almosny N.R.P., Cascardo B., Summa R.P. \& Cury L.J. 2006. Avaliação dos valores hematológicos em cavalos (Equus caballus) da raça Puro Sangue Inglês (PSI), submetidos a teste do esforço físico em esteira ergométrica. Revta Bras. Ciênc. Vet. 13(1):25-31. <http://dx.doi. org/10.4322/rbcv.2014.261>

Liesener K., Curtui V., Dietrich R., Märtlbauer E. \& Usleber E. 2010. Mycotoxins in horse feed. Mycotoxin Res. 26(1):23-30. <http://dx.doi.org/10.1007/ s12550-009-0037-8> <PMid:23605238>
McGowan C. 2008. Clinical pathology in the racing horse: the role of clinical pathology in assessing fitness and performance in the racehorse. Vet. Clin. N. Am., Equine Pract. 24(2):405-421 <http://dx.doi.org/10.1016/j. cveq.2008.03.001> <PMid:18652962>.

Mercosul/GMC 2002. Resolução no 25, Regulamento Técnico Mercosul sobre limites máximos de aflatoxinas admissíveis no leite, amendoim e milho. Mercado Comum do Cone Sul/Grupo Mercado Comum <http://portal. anvisa.gov.br/legislacao\#/>

NRC 2007. Nutrient Requirements of Horses. 6th ed. National Academies Press, Washington, D.C. 341p.

Oliveira C.A.A., Azevedo J.F., Miranda A.C.T., Souza B.G., Ramos M.T., Costa A.P.D., Baldani C.D., Silva V.P. \& Almeida F.Q. 2014. Hematological and blood gas parameters' response to treadmill exercise test in eventing horses fed different protein levels. J. Equine Vet. Sci. 34(11/12):1279-1285. <http:// dx.doi.org/10.1016/j.jevs.2014.09.007>

Padilha F.G.F., Dimache L.A.G., Almeida F.Q. \& Ferreira A.M.R. 2017. Blood biochemical parameters of Brazilian sport horses under training in tropical climate. Revta Bras. Zootec. 46(8):678-682. (Short Communication). <http://dx.doi.org/10.1590/s1806-92902017000800008>

Paludo G.R., McManus C., Melo R.Q., Cardoso A.G., Mello F.PS., Moreira M. \& Fuck B.H. 2002. Efeito do estresse térmico e do exercício sobre os parâmetros fisiológicos de cavalos do Exército Brasileiro. Revta Bras. Zootec. 31(3):11301142. <http://dx.doi.org/10.1590/S1516-35982002000500009>

Pösö A.R., Hyyppä S. \& Geor R.J. 2004. Metabolic responses to exercise and training. In: Hinchcliff K.W., Kaneps A.J., Geor R.J. (Eds), Equine Sports Medicine and Surgery. W.B. Saunders, Philadelphia, p.771-792.

Raymond S.L., Smith T.K. \& Swam H.V.L.N. 2005. Effects of feeding a blend of grains naturally contaminated with Fusarium mycotoxins on feed intake, metabolism, and indices of athletic performance of exercised horses. J. Anim.Sci. 83(6):1267-1273. <http://dx.doi.org/10.2527/2005.8361267x>

Reed S.M, Bayly W.M. \& Sellon D.C. 2004. Equine Internal Medicine. $2^{\mathrm{a}}$ ed. W.B. Saunders, Philadelphia. 1.650p.

Robinson N.E. 1997. Current therapy in equine medicine. W.B. Saunders, Philadelphia. 800p.

Rose R.J. \& Hodgson D.R. 1994. Hematology and biochemistry, p.63-79. In: Hodgson D.R. \& Rose R.J. (Eds), The Athletic Horse: principles and practice of equine sports medicine. W.B. Saunders, Philadelphia.

Ross P.F., Rice L.G., Reagor J.C., Osweiler G.D., Wilson T.M., Nelson H.A., Owens D.L., Plattner R.D., Harlin K.A., Richard J.L., Colvin B.M. \& Banton M.I. 1991. Fumonisin B1 Concentrations in Feeds from 45 Confirmed Equine Leukoencephalomalacia Cases. J. Vet. Diagn. Invest. 3(3):238-241. <http://dx.doi.org/10.1177/104063879100300310><PMid:1911996>

Rushing B.R. \& Selim M. 2019. AflatoxinB1: a review on metabolism,toxicity,occurrence in food occupational exposure, and detoxification methods. Food Chem. Toxicol. 124:81-100. <http://dx.doi.org/10.1016/j.fct.2018.11.047> <PMid:30468841>

SAEG 2007. Sistema de análises estatísticas e genéticas (SAEG), Versão 9.1. Universidade Federal de Viçosa (UFV), Viçosa, MG. 301p.

Santiago J.M., Almeida F.Q., Silva L.L.F., Miranda A.C.T., Azevedo J.F., Oliveira C.A.A. \& Carrilho S.S. 2013. Hematologia e bioquímica sérica de equinos de concurso completo de equitação em treinamento. Arq. Bras. Med. Vet. Zootec. 65(2):383-392. <http://dx.doi.org/10.1590/S0102-09352013000200013>

Schulz A-K., Kersten S., Dänicke S., Coenen M. \& Vervuert I. 2015. Effects of deoxynivalenol in naturally contaminated wheat on feed intake and health status of horses. Mycotoxin Res. 31(4):209-216. <http://dx.doi. org/10.1007/s12550-015-0234-6> <PMid:26420605>

Schumann B., Winkler J., Mickenautsch N., Warnken T. \& Dänicke S. 2016. Effects of deoxynivalenol (DON), zearalenone (ZEN), and related metabolites on equine peripheral blood mononuclear cells (PBMC) in vitro and background occurrence of these toxins in horses. Mycotoxin Res. 32(3):153-161. <http://dx.doi.org/10.1007/s12550-016-0250-1> <PMid:27255919> 
Shotwell O.L., Hesseltine C.V., Stubblefield R.D. \& Sorenson W.G. 1966. Production of aflatoxina on rice. Appl. Microbiol. 14(3):425-428. <PMid:5970829>

Sloet van Oldruitenborgh-Oosterbaan M. 1998. Appropriate blood variables helpful in diagnosing (sub)clinical disease in the horse, p.14-33. Lindner A. (Ed.), Conference on Equine Sports Medicine and Science. Cordoba, Spain. Wageningen Pers, Wageningen.

Snow D.H., Kerr M. \& Nimmo M. 1982. Alterations in blood, sweat, urine and muscle composition during prolonged exercise in the horse. Vet. Rec. 110(16):377-384. <http://dx.doi.org/10.1136/vr.110.16.377> $<$ PMid:7080430>

Thomassian A. 2005. Enfermidade dos Cavalos. 4⿳⺈ ed. Ed. Varela, São Paulo. 573p.
Thomassian A., Carvalho F., Watanabe M.J., Silveira V.F., Alves A.L.G., Hussni C.A. \& Nicoletti J.L.M. 2007. Atividades séricas da aspartato aminotransferase, creatina quinase e lactato desidrogenase de equinos submetidos a teste padrão de exercício progressivo em esteira. Braz. J. Vet. Res. Anim. Sci. 44(3):183-190.

Trucksess M.W., Stack M.E., Nesheim S., Albert R. \& Romer T. 1994. Multifunctional column coupled with liquid chromatography for determination of aflatoxins B1, B2, G1 and G2 in corn, almonds. Brazil nuts, peanuts, and pistachio nuts: collaborative study. J. AOAC Int. 77(6):1512-1521.<PMid:7819761>

Trueman K.F., Lumsden J.H. \& McSherry B.J. 1983. Examination of the origin of increased equine serum alkaline phosphatase concentrations. Can. Vet. J. 24(4):108-111.<PMid:17422242> 